\title{
Assessing the use of Hospital Information Systems (HIS) to support decision-making: A cross-sectional study in public hospitals in Huila, sanitary region of southern Angola.
}

Tomas Hambili Sanjuluca ( $\nabla$ tomashambili@yahoo.com.br)

Faculty of Medicine, Mandume Ya Ndemufayo University, Huila, Angola

Ricardo Cruz Correia

University of Porto

Anabela Antunes de Almeida

Faculty of Social and Human Sciences, University of Beira Interior-

\section{Research Article}

Keywords: Angola, Hospital Management, Hospital Information System, Support management-related Decision-making

Posted Date: July 29th, 2021

DOI: https://doi.org/10.21203/rs.3.rs-763372/v1

License: (c) (1) This work is licensed under a Creative Commons Attribution 4.0 International License.

Read Full License 


\section{Abstract \\ Background}

Some previous studies have reported that hospital medical assistance in Angola lacks efficiency. There is no production of information on health financing or even health spending that could help monitor equity. Hospital information systems (HIS) could be relevant tools to inform hospital managers, supporting better management decisions in healthcare and, consequently, increasing efficiency. Nonetheless, the effective use of these systems by hospital managers to support decision-making in Angola is unknown. This study aimed to analyze the use of HIS as a tool to support decision-making by hospital managers in Huila, Angola.

\section{Methods}

This is a descriptive-cross-sectional study that was inducted between July and September 2017 in seven hospitals in Huila Province, Angola, specifically in Lubango and Matala cities. Each hospital board included four to six managers (e.g., general, clinical, administrative, nursing, diagnostic and therapeutic, and teaching and training managers). Thirty-six members of the hospital boards filled on a selfquestionnaire that consisted of twenty questions based on the following issues: characterization of the interviewee's profile; availability of information in the institution; quality and usefulness of the available operational information and satisfaction with the existing HIS. Perform data analysis with IBM SPSS Statistics, version 21.0

\section{Results}

At least $\nabla$ of the participants reported being unsatisfied or relatively satisfied with each of the HIS-specific features that were assessed. More than $50 \%$ have rarely or never used the health information system to support decision-making, and $47.2 \%$ have never noted audits performed in their institution. Only $25 \%$ of the participants considered that the HIS stored information was satisfactory to calculate the rate of service indicators.

\section{Conclusion}

Our study showed that most hospital managers don't use hospital information systems as tools to support management-related decision-making in Angola. Improving the Hospital information systems, ability to compute adequate indicators, and providing training on HIS usage to hospital managers could be targets of future interventions to support better management-related decision-making in Angolan healthcare. 


\section{Background}

Some previous studies have reported that hospital medical assistance in Angola lacks efficiency. There is no information on health financing or even health spending that could help monitor equity. Hospital Information Systems (HIS) can support healthcare delivery, patient safety and satisfaction, and clinical practice as a whole ${ }^{1}$.

Information on mortality and causes of death often lacks nationally, as reliable death registration systems are not in place. The national census, generally conducted every ten years, can be a source of district-specific child mortality estimates in some countries ${ }^{2}$. Weak HIS is a critical challenge to reaching the health-related Millennium Development Goals because health systems performance cannot be adequately assessed or monitored where HIS data are incomplete, inaccurate, or untimely ${ }^{3}$.

Health systems' goal is to optimize the health of treated individuals and populations, and the "gold standard" for quality measurement will thus always be health outcome measures. HIS can be defined as the socio-technical subsystems of a hospital, comprising all information processing systems and the associated human or technical actors in their information processing roles 56,78910 .

Sound hospital information systems, computerized or not, should present timely the correct and appropriate information to the right persons. However, there are plenty of data sources in a hospital, many different functions with mutually complex relations, and many people dependent on this information 9111213 .

Given the enormous volume of data generated in hospitals, to efficiently manage them, using HIS is critical. User participation is one of the significant factors in the success of HIS that in turn leads Information needs and processes to be correctly predicted and their commitment to the development of HIS to be augmented ${ }^{9} 1415$.

Appropriate decisions taken by hospital managers are fundamental to ensure compliance with highquality standards of patient care. In addition, those decisions benefit from systematic information processing that contributes to achieving the hospital's strategic goals 57161718 .

Many studies are assessing if and how healthcare managers apply HIS in their decision processes. For example, in Portugal, hospital managers considered HIS a relevant tool in the institutional organization used in the decision process but only incidentally and not systematic ${ }^{19}$. Some difficulties raised by the professionals were the technical difficulty, the nonspecific system, lack of training, and the difficulty in producing effective processes to the demands of users ${ }^{20} 2122$. These results agree with a study carried out in Brazil, that the findings showed that ample amounts of information and data are available in public hospitals. However, it presents many gaps, and hospital managers do not know about the existing data and do not use it to guide hospital management ${ }^{18}$. 
There is some evidence that hospital managers' time spent and work can influence quality and safety clinical outcomes, processes, and performance. Many issues affect quality performance, such as establishing goals and strategies to improve care, setting the quality plan, engaging in quality, and so on 2324252627 .

It is the responsibility of the Angolan state to promote and guarantee the access of all citizens to health care within the limits of available human and financial resources. The organization of the health care delivery system in Angola subdivides into three hierarchical levels: ${ }^{28}$

- Primary level, represented by municipal health institutions (health centers and hospitals).

- The secondary or intermediate level is the reference level for first-level units, represented by provincial health institutions (general hospitals).

- The tertiary level is the reference for secondary level units. Represented by national health institutions, such as reference hospitals, differentiated or specialized or multipurpose hospitals.

Among other weaknesses that present the Angolan national health system, studies have identified the following as those that assume a particular relevance: (i) The difficulty of strategic articulation and coordination of health interventions and on the determinants of health; (ii) Weak leadership of the health sector; (iii) Poor planning capacity at all levels; (iv) Decentralization without financial autonomy for local health structures; (v) Poor management of resources made available at all levels; (vi) Investments inconsistent with health needs and priorities; (vii) Low transparency in management acts; (viii) Incipient information, communication, supervision, and evaluation system ${ }^{29}$.

The fundamental challenges to be faced when aiming to achieve a more efficient level of healthcare can be summarized in four central aspects: financing, management, access, and qualification of professionals. To improve these points, consistent and continuous policies are needed ${ }^{30}{ }^{31}$. In Angola, the direction of the hospital is performing by a board of directors composed of six directors. This board is responsible for performing all tasks related to managing hospital services of this aspect of clinical care to administrative.

All Information Systems are implemented and maintained by the hospitals without using national information systems made available by the health ministry. Nevertheless, the Health Ministry defines a set of indicators the hospitals need to calculate and send. These processes are still performed using paper to collect data and send it to the regional government and then to the national health ministry ${ }^{28}$.

As shown during the COVID pandemic, the way healthcare is managed in one place (e.g., new variants appearing in many different countries) in the world has the potential to have a huge impact elsewhere. Therefore, a call for better healthcare management and accurate data across the globe is needed 2932 .

Implementation of HIS systems has increased globally over the past five years, and higher-income countries are further adopting and utilizing HIS compared to lower-income countries ${ }^{33}$. 
It is essential to evaluate better the level of use of HIS and the corresponding barriers. Taking into account the relevance of the HIS in the daily life of health professionals, institutions, and patients, meeting the current organization and the general assumptions of the HIS in hospitals of Angola, the question is: "Has the Hospital Information System been used in the decision-making process by the managers of public hospitals in the Huila health region? What are the main difficulties and possibilities of improvement to qualify the hospital information system's decision-making process?

Based on this questioning, this study aimed to analyze the use of the hospital information system as a tool to support the decision-making process by hospital managers in Huila province in Angola.

\section{Methods}

\section{Study Design}

It was a cross-sectional, questionnaire-based, observational study with a quantitative and qualitative approach. Data collection was held from July to December 2017 in seven hospitals from Huila, Angola. The study was authorized by the provincial Health Director of Huila.

\section{Study Setting}

Angola is organized in 18 provinces and, in the last Census (held in 2014), had almost 26 million inhabitants. Luanda is the biggest province, followed by Huila, which hosts 2.5 million inhabitants. Huila province includes 14 cities with a population ranging between 64 and 776 thousand citizens ${ }^{34}$.

Data from 2006-2010 estimated that Angola had 2356 public healthcare institutions, including, among others, 165 municipal hospitals, 25 province hospitals, and 20 central hospitals. Huila had the secondhighest healthcare institutions ( $n=232)$, just after South Kwanza $(n=244)$.

\section{Hospital selection process}

We used a two-step selection process. First, we identified the Huila cities with more than 200.000 inhabitants. Lubango (the capital) and Matala are the cities with the most significant number of inhabitants and only met this criteria ${ }^{34}$.

Secondly, we selected, within those cities, hospitals with at least 50 beds for inpatient hospitalization. For example, Lubango has five provincial hospitals and four municipal hospitals, while Matala has only one municipal hospital. Overall, seven hospitals (78\%) met the inclusion criteria (six hospitals in Lubango e one hospital in Matala).

\section{Questionnaire}

We used a self-questionnaire adapted from those described by Guimarães et al. and Cavalcante et al. ${ }^{35}$ 21. 
The questionnaire had 20 questions, with four main focuses: characterization of the interviewee's profile; availability of information in the institution; quality and usefulness of the available operational information; satisfaction with the existing HIS.

Both closed and open questions were included, depending on the target information (e.g., available questions to obtain unbiased information related to HIS difficulties and enhancement suggestions).

A pilot study was conducted with 15 Angolan students from the specialization course of the health management course at the professional health school of Huila to assess the comprehensibility and ease of filling of the study's self-questionnaire. They suggested some changes to the questions, considering the country context, which was viewed in the final questionnaire.

\section{Participants and data collection}

After being tested and approved, the questionnaire was applied in public sector health institutions, with an authorization order, for the study to be carried out, signed by the director of the health region of Huila. All members of the institutional board of the selected hospitals were invited to participate in this study. Usually, the committee included four to six managers with different tasks: general, clinical, administrative, nursing, diagnostic and therapeutic, and teaching and training managers (Table 1). Within each institution, the respective hospital director was responsible for distributing the questionnaire to all managers, guiding them through filling, and clarifying any doubt. Whenever needed, contacted the responsible study team to provide further clarification.

\section{Data analyses}

Categorical data were analyzed using descriptive statistics, including absolute and relative frequencies. Perform data analysis with IBM SPSS Statistics, version 21.0

\section{Results}

Thirty-six hospital managers participated in this study (Table 1). All hospitals had general, clinical, administrative, and nursing managers; six had teaching and training managers, and only two had diagnostic and therapeutic managers.

Table 1 - Hospital managers interviewed in each organization 


\begin{tabular}{|c|c|c|c|c|c|c|c|c|}
\hline $\begin{array}{l}\text { Position / } \\
\text { Hospital }\end{array}$ & $\begin{array}{l}\text { Dr. AA Neto } \\
\text { Central } \\
\text { Hospital }\end{array}$ & $\begin{array}{l}\text { C/da Irene } \\
\text { Maternity } \\
\text { Hospital }\end{array}$ & $\begin{array}{l}\text { Lubango } \\
\text { Sanatorium } \\
\text { Hospital }\end{array}$ & $\begin{array}{l}\text { Pioneiro } \\
\text { Zeca } \\
\text { Pediatric } \\
\text { Hospital }\end{array}$ & $\begin{array}{l}\text { Lubango } \\
\text { psychiatric } \\
\text { Hospital }\end{array}$ & $\begin{array}{l}\text { Matala } \\
\text { Municipal } \\
\text { Hospital }\end{array}$ & $\begin{array}{l}\text { Lubango } \\
\text { Municipal } \\
\text { Hospital }\end{array}$ & Total \\
\hline $\begin{array}{l}\text { General } \\
\text { manager }\end{array}$ & $\mathrm{x}$ & $\mathrm{x}$ & $\mathrm{x}$ & $\mathrm{x}$ & $\mathrm{x}$ & $\mathrm{x}$ & $\mathrm{x}$ & 7 \\
\hline $\begin{array}{l}\text { Clinical } \\
\text { manager }\end{array}$ & $\mathrm{x}$ & $\mathrm{x}$ & $\mathrm{x}$ & $\mathrm{x}$ & $\mathrm{x}$ & $\mathrm{x}$ & $\mathrm{x}$ & 7 \\
\hline $\begin{array}{l}\text { Administrative } \\
\text { manager }\end{array}$ & $\mathrm{x}$ & $\mathrm{x}$ & $\mathrm{x}$ & $\mathrm{x}$ & $\mathrm{x}$ & $\mathrm{x}$ & $\mathrm{x}$ & 7 \\
\hline $\begin{array}{l}\text { Nursery area } \\
\text { manager }\end{array}$ & $\mathrm{x}$ & $\mathrm{x}$ & $\mathrm{x}$ & $\mathrm{x}$ & $\mathrm{x}$ & $\mathrm{x}$ & $\mathrm{x}$ & 7 \\
\hline $\begin{array}{l}\text { Diagnostic and } \\
\text { therapeutic } \\
\text { manager }\end{array}$ & $\mathrm{x}$ & $\mathrm{x}$ & - & - & - & - & - & 2 \\
\hline $\begin{array}{l}\text { Teaching and } \\
\text { training } \\
\text { manager }\end{array}$ & $\mathrm{x}$ & $\mathrm{x}$ & $\mathrm{x}$ & $\mathrm{x}$ & $\mathrm{x}$ & $\mathrm{x}$ & - & 6 \\
\hline $\begin{array}{l}\text { Total of } \\
\text { managers by } \\
\text { hospital }\end{array}$ & 6 & 6 & 5 & 5 & 5 & 5 & 4 & 36 \\
\hline
\end{tabular}

* (X) Answered the questionnaire ; (-) Did not answer the questionnaire (due to absence)

\section{Characterization of the interviewee's profile}

Around $3 / 4$ of the participants were 40 or more years old (table 2). Most were nurses (44\%) or physicians $(42 \%)$ and had less than five years of experience in hospital management $(83 \%)$. 
Seventy-two percent of the participants had attended basic computer training, $61 \%$ had training in health statistics, and $58 \%$ participated in a training program in health management. Additional participant characteristics are described in (table 2).

Table 2 - Characterization of the participant's profile $(n=36)$

\begin{tabular}{|c|c|c|}
\hline Variables & $n$ & $\%$ \\
\hline Sex, male & 18 & 50 \\
\hline \multicolumn{3}{|l|}{ Age categories, years } \\
\hline$\leq 30$ & 3 & 8.3 \\
\hline $31-40$ & 7 & 19.4 \\
\hline $41-50$ & 19 & 52.8 \\
\hline$\geq 50$ & 7 & 19.4 \\
\hline \multicolumn{3}{|l|}{ Profession } \\
\hline Nurse & 16 & 44.4 \\
\hline Physician & 15 & 41.7 \\
\hline Psychologist & 3 & 8.3 \\
\hline Hospital administrative & 1 & 2.8 \\
\hline Physiotherapy technician & 1 & 2.8 \\
\hline Laboratory technician & 1 & 2.8 \\
\hline \multicolumn{3}{|l|}{ Academic qualifications } \\
\hline Bachelor degree & 16 & 44.4 \\
\hline Specialization & 15 & 41.7 \\
\hline Master's degree & 3 & 8.3 \\
\hline Other & 2 & 5.6 \\
\hline \multicolumn{3}{|c|}{ Experience in the institution, years } \\
\hline 1 to 5 & 4 & 11.1 \\
\hline 6 to 10 & 10 & 27.8 \\
\hline 11 to 15 & 9 & 25 \\
\hline$>15$ & 13 & 36.1 \\
\hline \multicolumn{3}{|c|}{ Experience in hospital management (years) } \\
\hline 1 to 5 & 30 & 83.3 \\
\hline 6 to 11 & 3 & 8.3 \\
\hline$>11$ & 3 & 8.3 \\
\hline \multicolumn{3}{|l|}{ Training courses } \\
\hline Had training in informatics & 26 & 72.2 \\
\hline Had health statistics training & 14 & 38.9 \\
\hline Had health management program training & 21 & 58.3 \\
\hline
\end{tabular}

\section{Availability of information within the selected institutions}

Sixty-four percent of the participants reported that data availability was reasonably acceptable, and $11 \%$ considered it unacceptable. 
Forty-four percent of the managers reported never use the available information in decision-making regarding patient care; $8 \%$ used it rarely and $33 \%$ sometimes. Regarding the support for clinical or administrative decision-making, nearly $39 \%$ of the participants reported never use this support, $11 \%$ used it rarely, and $28 \%$ sometimes (table 3 ).

Table 3 - Use of information for decision making (clinical and administrative) $(n=36)$

\begin{tabular}{|c|c|c|c|c|}
\hline \multirow[t]{2}{*}{ Questions } & \multirow{2}{*}{$\begin{array}{c}\text { Always } \\
\mathrm{n}(\%)\end{array}$} & \multirow{2}{*}{$\begin{array}{c}\text { Sometimes } \\
\mathrm{n}(\%)\end{array}$} & \multirow{2}{*}{$\begin{array}{c}\text { Rarely } \\
\mathrm{n}(\%)\end{array}$} & \multirow{2}{*}{$\begin{array}{c}\text { Never } \\
\mathrm{n}(\%)\end{array}$} \\
\hline & & & & \\
\hline Have you used the services of Admission, archives, and medical statistics to assist a & $5(13.9)$ & $12(33.3)$ & $3(8.3)$ & $16(44.4)$ \\
\hline \multicolumn{5}{|l|}{ patient who returns to the appointment after more than 30 days of hospitalization at your } \\
\hline \multicolumn{5}{|l|}{ institution? } \\
\hline Regarding the level of support for clinical or administrative decision-making, have you & $8(22.2)$ & $10(27.8)$ & $4(11.1)$ & 14(38.9) \\
\hline \multicolumn{5}{|l|}{ used the information provided by the Admissions, Archives, and Medical Statistics } \\
\hline services? & & & & \\
\hline
\end{tabular}

\section{Quality and usefulness of the available operational information}

Only $25 \%$ of the participants considered that the HIS stored information was satisfactory to calculate the rate of service indicators; $42 \%$ considered it partially adequate, and $33 \%$ believed that the stored information did not compute indicators.

According to $47 \%$ of the participants, there was an absence of audit sessions to assess the quality of information described in the clinical records sent to admission, archive, and health statistics services.

These study participants reported that the most relevant limitations regarding the information access process were: the lack of important/required information in the available dashboards (24\%), shortage of IS specialists (22\%), excessive data volume (19\%), and insufficient communication channels between the technical and management levels (19\%).

The most priority information requirements were computerization of all information on hospital activities $(39 \%)$, organization of file systems (31\%), and automatic computing of indicators (28\%).

\section{Satisfaction with the existing HIS}


At least $\nabla$ of the participants reported being unsatisfied or relatively satisfied with each of the HIS specific features assessed (security and archive mechanisms used for clinical files, access to relevant information, sharing of information among hospital services, clinical file information content, and comprehensibility) (table 4).

No more than $9 \%$ were delighted with any of the assessed features. Furthermore, three-quarters of the participants reported that their institutions had no software project or investment policy regarding electronic health records. Nevertheless, they were unanimous in considering that it could improve hospital performance using information technology.

Table 4: Assessment of participants satisfaction with Hospital information systems $(n=36)$

\begin{tabular}{|c|c|c|c|c|}
\hline Questions & $\begin{array}{l}\text { Very } \\
\text { satisfied }\end{array}$ & Satisfied & $\begin{array}{l}\text { Fairly } \\
\text { satisfied }\end{array}$ & Unsatisfied \\
\hline & $\mathrm{n}(\%)$ & $n(\%)$ & $\mathrm{n}(\%)$ & $\mathrm{n}(\%)$ \\
\hline $\begin{array}{l}\text { a user of the Hospital Information System, how do you assess the security and } \\
\text { hiving mechanisms of clinical processes? }\end{array}$ & $1(2.8)$ & $7(19.4)$ & $15(41.7)$ & $13(36.1)$ \\
\hline $\begin{array}{l}\text { a user of the Hospital Information System, how do you evaluate the access to } \\
\text { Irmation needed for your daily work? }\end{array}$ & $1(2.8)$ & $7(19.4)$ & $11(30.6)$ & $17(47.2)$ \\
\hline $\begin{array}{l}\text { a user of the Hospital Information System, how do you evaluate the sharing of } \\
\text { irmation in the same institution between different services (by doctors and } \\
\text { ses)? }\end{array}$ & $2(5.6)$ & $7(19.4)$ & 14(38.9) & 13(36.1) \\
\hline $\begin{array}{l}\text { ə user of the Hospital Information System, how do you evaluate the information } \\
\text { tent of the clinical process model? }\end{array}$ & $2(5.6)$ & $9(25)$ & $\begin{array}{c}12 \\
(33.3)\end{array}$ & $13(36.1)$ \\
\hline $\begin{array}{l}\text { a user of the Hospital Information System, how do you evaluate the information } \\
\text { ıprehensibility of the clinical process model? }\end{array}$ & $3(8.3)$ & $9(25)$ & $9(25)$ & $15(41.7)$ \\
\hline
\end{tabular}

\section{Discussion}

\section{Statement of principal findings}

This study analyzed the reality of hospital managers in the health region of Huilla in Angola regarding using the HIS as a tool to support the decision-making process. The analysis of the questionnaires to thirty-six managers from seven hospitals that participated in the study revealed that hospital managers 
do not use the HIS to support decision-making, both for clinical and administrative aspects. In addition, the participants expressed an assessment of dissatisfaction with the HIS.

\section{Strengths and limitations}

The main strengths of this study are the fact there are very few studies on health informatics in the large region of Southern Africa, a region that has more than 210 million inhabitants. Also, this work gives a very clear picture of an Angola province (Huila), covering all but the military hospitals. In the current pandemic moment, having this picture of less-studied but very populated regions is critical to support worldwide efforts.

However, this study has some limitations. First, in this study, only Huila province was assessed. Although the main cities of Huila (Lubango and Matala) are among the most populated cities in Angola, we believe that it would be interesting to include a broader sample to picture better the Angolan use of HIS for decision-making in hospital management. Moreover, in the study's questionnaire, additional questions assessing specific characteristics of the HIS that are in use at each hospital would be helpful. Finally, we assessed HIS-related perceptions, but we cannot guarantee that all hospitals used the same specific HIS (which can drive diverging perceptions as their features might be different).

\section{Interpretation within the context of the wider literature}

To the best of our knowledge, this is the first study analyzing the use of HIS as a tool to support decisionmaking by hospital managers in Angola. This study involved the main actors responsible for hospital management (e.g., clinical, nursery, administrative manager), most with a long experience within the institution and a good knowledge of the available HIS. We understand that these are vital aspects when looking for a critical view about what ought to be changed or enhanced on HIS and strengthening our findings.

Some studies have shown that a high educational level of healthcare managers can improve patient care and data quality. However, our study noted that most respondents had a minimum level of education (bachelor's degree), which could make our results less generalizable to settings where most hospital managers are highly schooled.

Previous studies have shown that having informatic courses/training could significantly affect competencies levels ${ }^{36}$. However, in our study, despite most of the respondents had complementary informatics training, they did not have health statistics training, which would be very important to improve their data understanding and practical application. This lack of exercise may be related to the absence of specific health informatics curricula in many health-related schools (e.g., medical and nursing $)^{37}$. However, should actively pursue training in health management to enable hospital managers to effectively improve the decision by making better use of the vast amount of data produced within each healthcare institution 243839 . 
We found that half of the participants had never or rarely used HIS information to support decisionmaking regarding hospital management in Angola. However, in other countries, such as Iran and Brazil, some studies found that hospital managers frequently used evidence-based hospital management and acknowledged that HIS is a relevant tool to the institutional organization and should be used during the decision process ${ }^{11} 213540$. Found Similar results in a study conducted in the Brong Ahafo region in Ghana on Utilization of the national cluster of district health information system (DHIMS2)for health service decision-making at the district, subdistrict, and community levels, where found that although $93 \%$ of the health facilities studied submitted data to the DHIMS2 platform, the evidence suggested low use of these data in decision making ${ }^{41}$.

Otherwise, in Angola, we found that most of our participants regarded HIS as inadequate or fairly adequate tools, with excessive data volume but lacking relevant information (e.g., to compute healthcare indicators) and proper communication channels, leading to general dissatisfaction with HIS features. Although these aspects can be "true" limitations of HIS, we cannot exclude that a possible lack of training in HIS parts might also influence hospital managers' perceptions. Another study held in Brazil found that ample amounts of information and data were available but that managers did not know about existing data and did not use that information to guide hospital management ${ }^{20}$.

Auditing procedures are fundamental to assess the information pathway and guarantee that recommended data collection, storage, and access procedures are fulfilled; it allows the early identification of system misuse and enable the intelligent implementation of preventive and corrective measures ${ }^{30} 42$. However, we found that almost half of the participants reported that they never performed information-related audit procedures in their institutions. Findings from several studies invoke the critical need for formal and informal training in health management for health managers, emphasizing members of hospital boards ${ }^{714}$ 22. Most hospitals in higher-income countries use comprehensive HIS, while in other parts of the world, hospital orders for medications, laboratory tests, and other services are still paper-based $^{33} 43$.

Our participants reported that they did not appeal to admission, archive, and medical statistics services to examine a patient returning to an appointment after 30 days. In other words, we can say that for patients registered to a meeting, if they return to the hospital after more than 30 days, a new admission will be performed, ignoring information collected in the appointment before.

Moreover, hospital managers' use of HIS information seems to be influenced by several factors such as age, personal motivation, work commitment, work experience, and so on ${ }^{17} 44$. Some of these factors might affect our findings in Angola. For example, although our study's participants had long experience within the institution, more than $80 \%$ worked in hospital management for less than five years. Did not assess personal motivation and work commitment in this study. The studies conducted show that longer follow-up is needed to evaluate the sustainability of programs in developing countries ${ }^{6} 2645$. Anther 
findings support that HIS functions in Turkish hospitals are generally not as available as quality managers would like ${ }^{13}$.

\section{Implications for policy, practice, and research}

However, the weaknesses of the HIS have limited managers to resorting to this essential support tool for the decision-making process. For example, the HIS for-budget plans should be a procedure legislated by the Angolan government. Creating rules and guidelines for hospital financing based on information will create new information systems that will improve quality. Would motivate managers to strengthen and use hospital information to make clinical and administrative decisions ${ }^{24} 46$. This study stresses the need to invest in the organization and health information technologies in Angola to gather data needed to support the decision process locally, in the province, and the country.

Various researchers have posited that more investment is necessary for health infrastructure. Hospital information systems may contribute in different ways to quality assurance activities such as assessing the quality of primary care, monitoring quality indicators, supporting clinical care evaluation studies, and auditing concurrently the ongoing care process using reminders or decision support techniques. However, to meet all requests of quality assurance in real-world settings, many efforts to develop new technologies will still be necessary.

Regarding the hospital managers, this study shows that they need to change how their work is performed to use the existing data collected in hospitals. The increase in such data will also improve its quality and usefulness in the long run.

Our results show the need to understand better the underlying causes and possible solutions for the underuse of HIS and its data in hospital management. It is not just a question of whether the technology is available, human aspects like motivation or institutional organization need to be central.

Also, the reality found has a significant impact on the possibility to perform clinical and epidemiological research. Primary administrative and clinical data are essential to follow populations' health, and this data often comes from the executive or financial departments ${ }^{29}$.

\section{Conclusions}

Our findings support the conclusion that most hospital managers don't use HIS as a tool to support management-related decision-making in Angola. In addition, the lack of relevant information to calculate reported indicators is one of the significant limitations of the available information systems. Finally, further investment to improve the HIS ability to compute adequate indicators and provide training on HIS usage to hospital managers across organizational levels could be targets of future interventions to support better management-related decision-making in Angolan healthcare. 


\section{List Of Abbreviations}

HIS- Hospital information systems

\section{Declarations}

\section{Ethics approval and consent to participate}

. Not applicable. But the realization of the study with the application of the questionnaire (anonymous and confidential) in the public health institution selected for the study had authorization from the director of the health region of Huila. The previous order guided the general directors of this health institution to collaborate and provide all the support needed to carry out the research work.

\section{Consent for publication}

Not applicable

\section{Availability of data and materials}

'Not applicable. But the data sets used or analyzed during the study are available in the manuscript tables. Available from the corresponding author.

\section{Competing interests}

The authors declare that they have no competing interests

\section{Funding}

This research received no specific grant from any funding agency in public, commercial or not-for-profit sectors.

\section{Authors' contributions}

All authors who made substantial contributions to the conception and design of the study were involved in preparing and revising the manuscript until the final version's approval. Tomas Hambili (MSC) was responsible for bibliographic research, manuscript, data collection, and statistical analysis. The authors Anabela Almeida (Ph.D.) and Ricardo Correia (Ph.D.) Actively contributed to all parts of the article, including interpreting the text's data, revision, and approval. In addition, all authors contributed to the development of the data collection instrument.

\section{Acknowledgments}

The authors acknowledge the Provincial Health Directorate of Huila for permission to carry out the present study and appreciate the collaboration of hospital managers and those responsible for the admission of medical archives and statistics sections of hospitals. 


\section{References}

1. Connor C, Averbug C, Miralles M. Avaliação do Sistema de saúde de Angola 2010. Bethesda: Abt Associates Inc. 2010.

2. Mathers CD, Ma Fat D, Inoue M, Rao C, Lopez AD. Counting the dead and what they died from: an assessment of the global status of cause of death data. Bulletin of the world health organization. 2005;83:171-7c. https://apps.who.int/iris/handle/10665/72966

3. Jha P, Mills A, Hanson K, Kumaranayake L, Conteh L, Kurowski C, et al. Improving the health of the global poor. Science. 2002;295(5562):2036-9. DOI: 10.1126/science.295.5562.2036

4. Organization WH. Health Metrics Network. Framework and standards for country health information systems, Geneva; 2008. 2010.. https://apps.who.int/iris/handle/10665/43872

5. Haux R, Ammenwerth E, Winter A, Brigl B. Strategic information management in hospitals: an introduction to hospital information systems: Springer Science \& Business Media; 2004. doi.org/10.1007/978-1-84996-441-8_9

6. Nasir N, Marikar K. Does Adoption of Health Information System (HIS) in Hospital Affect the Compliance to the Hospital Accreditation Program: ISQUA18-2296. International Journal for Quality in Health Care. 2018;30:12-3. doi.org/10.1093/intqhc/mzy167.15

7. Dagnew E, Woreta SA, Shiferaw AM. Routine health information utilization and associated factors among health care professionals working at public health institutions in North Gondar, Northwest Ethiopia. BMC health services research. 2018;18(1):1-8. doi.org/10.1186/s12913-018-3498-7

8. Ben-Assuli O, Shabtai I, Leshno M. The impact of EHR and HIE on reducing avoidable admissions: controlling main differential diagnoses. BMC medical informatics and decision making. 2013;13(1):49. doi.org/10.1186/1472-6947-13-49

9. Heponiemi T, Hyppönen H, Kujala S, Aalto A-M, Vehko T, Vänskä J, et al. Predictors of physicians' stress related to information systems: a nine-year follow-up survey study. BMC health services research. 2018;18(1):1-9. doi.org/10.1186/s12913-018-3094-x

10. Begum T, Khan SM, Adamou B, Ferdous J, Parvez MM, Islam MS, et al. Perceptions and experiences with district health information system software to collect and utilize health data in Bangladesh: a qualitative exploratory study. BMC health services research. 2020;20:1-13. doi.org/10.1186/s12913020-05322-2

11. Prins $\mathrm{H}$, Kruisinga F, Buller $\mathrm{H}$, Zwetsloot-Schonk J. Availability and usability of data for medical practice assessment. International Journal for Quality in Health Care. 2002;14(2):127-37.. doi.org/10.1093/oxfordjournals.intqhc.a002599

12. Selbmann $H$, Pietsch-Breitfeld B. Hospital information systems and quality assurance. International Journal for Quality in Health Care. 1990;2(3-4):335-44. doi.org/10.1093/intqhc/2.3-4.335

13. Saluvan M, Ozonoff A. Functionality of hospital information systems: results from a survey of quality directors at Turkish hospitals. BMC medical informatics and decision making. 2018;18(1):112. doi.org/10.1186/s12911-018-0581-2 
14. Kpobi L, Swartz L, Ofori-Atta AL. Challenges in the use of the mental health information system in a resource-limited setting: lessons from Ghana. BMC health services research. 2018;18(1):1-8. doi.org/10.1186/s12913-018-2887-2

15. Wilms MC, Mbombela O, Prytherch H, Hellmold P, Kuelker R. An in-depth, exploratory assessment of the implementation of the National Health Information System at a district-level hospital in Tanzania. BMC health services research. 2014;14(1):1-14. doi.org/10.1186/1472-6963-14-91

16. Kohn MK, Berta W, Langley A, Davis D. Evidence-based decision making in health care settings: From theory to practice. Biennial Review of Health Care Management (Advances in Health Care Management). 2011:215-34. oi.org/10.1108/S1474-8231(2011)0000011012

17. Krenyácz É. Use of management information in hospital decision-making. VezetéstudományBudapest Management Review. 2018;49(5):2-12. doi.org/10.14267/VEZTUD.2018.05.01

18. Pereira SR, Paiva PB, de Souza PRS, Siqueira G, Pereira AR. Sistemas de Informação para Gestão Hospitalar. Journal of Health Informatics. 2012;4(4).

19. Gaspar Cruz S, Frederico Ferreira MM. Knowledge management in Portuguese healthcare institutions. Revista brasileira de enfermagem. 2016;69(3). doi.org/10.1590/00347167.2016690311i

20. Junior ÁE. Information use in public hospital management. Ciencia \& saude coletiva. 2007;12(3):655. doi.org/10.1590/S1413-81232007000300015

21. Cavalcante RB, Cunha SGS, Bernardes MFVC, Gontijo TL, de Azevedo Guimarães EA, da Conceição Oliveira V. Sistema de Informação Hospitalar: utilização no processo decisório. Journal of Health Informatics. 2012;4(3).

22. Ochonma OG, Nwatu SI. Assessing the predictors for training in management amongst hospital managers and chief executive officers: a cross-sectional study of hospitals in Abuja, Nigeria. BMC medical education. 2018;18(1):1-11. doi.org/10.1186/s12909-018-1230-2

23. Hejazi SM, Ghasemi M, Hadian M, Mohammadnjad R. Hospital Information System, a Tool for Effective Decision Making of Healthcare Managers. International Journal of Hospital Research. 2016;5(3):107 - 12. doi.10.15171/ijhr.2016.20

24. Kebede S, Abebe Y, Wolde M, Bekele B, Mantopoulos J, Bradley EH. Educating leaders in hospital management: a new model in Sub-Saharan Africa. International Journal for Quality in Health Care. 2010;22(1):39-43. doi.org/10.1093/intqhc/mzp051

25. Parand A, Dopson S, Renz A, Vincent $C$. The role of hospital managers in quality and patient safety: a systematic review. BMJ Open. 2014;4(9):e005055. dx.doi.org/10.1136/bmjopen-2014-005055

26. Bradley E, Hartwig KA, Rowe LA, Cherlin EJ, Pashman J, Wong R, et al. Hospital quality improvement in Ethiopia: a partnership-mentoring model. International Journal for Quality in Health Care. 2008;20(6):392-9.. doi.org/10.1093/intqhc/mzn042

27. Abbasi-Moghaddam MA, Zarei E, Bagherzadeh R, Dargahi H, Farrokhi P. Evaluation of service quality from patients' viewpoint. BMC Health Services Research. 2019;19(1):1-7. doi.org/10.1186/s12913019-3998-0 
28. Oliveira MdSd, Artmann E. Regionalização dos serviços de saúde: desafios para o caso de Angola. Cadernos de Saúde Pública. 2009;25(4):751-60.

29. Heiby J. The use of modern quality improvement approaches to strengthen African health systems: a 5-year agenda. International Journal for Quality in Health Care. 2014;26(2):117-23. doi.org/10.1093/intqhc/mzt093

30. Ramjee S, Hauck K, Burger R, Stewart J. Narrowing the gap: hospital accreditation and inequality in South Africa. 2016.. dx.doi.org/10.1093/intqhc/mzw104.53

31. Mutale W, Chintu N, Amoroso C, Awoonor-Williams K, Phillips J, Baynes C, et al. Improving health information systems for decision making across five sub-Saharan African countries: Implementation strategies from the African Health Initiative. BMC health services research. 2013;13(2):1-12. doi.org/10.1186/1472-6963-13-S2-S9

32. Kalichman SC, Shkembi B, Kalichman MO, Eaton LA. Trust in health information sources and its associations with COVID-19 disruptions to social relationships and health services among people living with HIV. BMC public health. 2021;21(1):1-12. doi.org/10.1186/s12889-021-10856-Z

33. Organization WH. Global diffusion of eHealth: making universal health coverage achievable: report of the third global survey on eHealth: World Health Organization; 2017.

34. INE GDA. Resultados definitivos do recenseamento geral da população e habitação de Angola _Provincia da Huíla 2014. Luanda; 2016.

35. Guimarães EMP, Évora YDM. Sistema de informação: instrumento para tomada de decisão no exercício da gerência. Ciência da informação. 2004;33(1):72-80. doi.org/10.1590/S010019652004000100009

36. Yang $L$, Cui $D$, Zhu $X$, Zhao Q, Xiao N, Shen X. Perspectives from nurse managers on informatics competencies. The Scientific World Journal. 2014;2014. doi.org/10.1155/2014/391714

37. Murphy J, Stramer K, Clamp S, Grubb P, Gotland J, Davis S. Health informatics education for clinicians and managers-what's holding up progress? International journal of medical informatics. 2004;73(2):205-13. doi.org/10.1016/j.ijmedinf.2003.12.003

38. Wagner C, Mannion R, Hammer A, Groene O, Arah O, Dersarkissian M, et al. The associations between organizational culture, organizational structure, and quality management in European hospitals. International Journal for Quality in Health Care. 2014;26(suppl_1):74-80. DOI:

10.1093/intqhc/mzu027

39. Ochonma OG, Nwatu SI. Assessing the predictors for training in management amongst hospital managers and chief executive officers: a cross-sectional study of hospitals in Abuja, Nigeria. BMC medical education. 2018;18(1):138. doi.org/10.1186/s12909-018-1230-2

40. Janati A, Hasanpoor E, Hajebrahimi S, Sadeghi-Bazargani H. Health care managers' perspectives on the sources of evidence in evidence-based hospital management: A qualitative study in Iran. Ethiopian Journal of health sciences. 2017;27(6):659 - 68. DOI: 10.4314/ ejhs.v27i6.11

41. Odei-Lartey EO, Prah RKD, Anane EA, Danwonno H, Gyaase S, Oppong FB, et al. Utilization of the national cluster of district health information system for health service decision-making at the 
district, sub-district, and community levels in selected districts of the Brong Ahafo region in Ghana. BMC health services research. 2020;20:1-15. doi.org/10.1186/s12913-020-05349-5

42. Cruz-Correia R, Boldt I, Lapão L, Santos-Pereira C, Rodrigues PP, Ferreira AM, et al. Analysis of the quality of hospital information systems audit trails. BMC medical informatics and decision making. 2013;13(1):84. 4. doi.org/10.1186/1472-6947-13-84

43. Borycki E, Newsham D, Bates D. eHealth in North America. Yearbook of medical informatics. 2013;22(01):103-6. DOI: 10.1055/s-0038-1638839

44. Ferreira-Da-Silva A, Fernandez-Feijoo B, Rodriguez SG, editors. Accounting information system and clinical decision-making. 5th Annual EuroMed Conference of the EuroMed Academy of Business; 2012.

45. Moucheraud C, Schwitters A, Boudreaux C, Giles D, Kilmarx PH, Ntolo N, et al. Sustainability of health information systems: a three-country qualitative study in southern Africa. BMC health services research. 2017;17(1):1-11. doi.org/10.1186/s12913-016-1971-8

46. Schneider EC. Hospital quality management: a shape-shifting cornerstone in the foundation for highquality health care. Oxford University Press; 2014. doi.org/10.1093/intqhc/mzu028 